FILOZOFIA

Roč. 76, 2021, č. 1

DOI: https://doi.org/10.31577/filozofia.2021.76.1.5

\title{
EPISTEMOLOGICKÁ PREKÁŽKA A „STRÁŽCA PRAHU“ U GASTONA BACHELARDA
}

ANTON VYDRA, Trnavská univerzita v Trnave, Filozofická fakulta, Katedra filozofie, Trnava, SR

VYDRA, A.: Epistemological Obstacle and "the Guardian of Threshold" in Gaston Bachelard

FILOZOFIA, 76, 2021, No 1, pp. 59 - 71

This article focuses on a crucial topic of epistemology in French philosopher Gaston Bachelard: epistemological obstacle. Through bachelardian psychanalysis of scientific mind and its neuroses the author puts a question, if a term of "the guardian of threshold", used by phenomenological psychotherapy based by Robert Desoille within a method of daydreaming, is or is not narrative reference to analytical thinking about the meaning of epistemological obstacle, which stops scientific knowledge in its progress. The author develops the issue of Bachelard's rationalism through his own genuine phenomenology, or anthropology of studying man as a man of "twenty-four hours", but also through Bachelard's analyses of epistemological obstacle described in his The Formation of the Scientific Mind (originally from year 1938). Between philosophy of reached erudition (by Bachelard own words, a senile state of science) and philosophy, which permanently visits a school, learns and reorganises its knowledge (youth of science) is a dialectical motion of historical epistemology. The science opened to consciousness of its own errors in ways, by which it reaches its knowledge, is for Bachelard materialized in the imagination of overcoming an obstacle, for example such obstacle, which is described by image of the guardian of threshold.

Keywords: Epistemological obstacle - Guardian of threshold - Liminality - Psychanalysis of scientific mind - Historical epistemology - Phenomenology of studying person

Jean-Michel Wavelet v nedávno vydanej biografickej práci Gaston Bachelard, l'inattendu (Gaston Bachelard - neočakávaný) tvrdí, že poetické a vedecké spisy Gastona Bachelarda by sa nemali brat' ako od seba nezávislé typy jeho spisby, ale ako na seba odkazujúce práce. Bachelard čítal poetické texty práve preto, že „ich používal na to, aby cez ne poukázal na prekážky, ktoré zväzujú poznanie, aby opísal bludné cesty rozumu, ktorý sa ocitá $\mathrm{v}$ zmätkoch, alebo aby nimi objasnil kreatívny proces“ (Wavelet 2019, 13).

V tomto texte si za kl'úč k pochopeniu tejto referenciality Bachelardovej poetiky a vedy vezmeme termín, ktorý bol najprv oblúbeným výrazom teozofov devätnásteho 
storočia (napríklad Rudolfa Steinera), hoci jeho dejiny siahajú omnoho hlbšie do minulosti, no ktorý sa stal takisto prvkom jednej časti fenomenologickej psychoterapie, ktorá pracovala s metódou bdelého snenia. Týmto pojmom je strážca prahu, personifikácia prekážky, ktorá bdie nad prahom l'udských obydlí a oddel'uje vnútrajšok od vonkajška, čím znemožňuje otvorit' dynamický proces transgresie.

Naša otázka znie: Je strážca prahu poetickým naratívom opisujúcim to, čo Gaston Bachelard v analytických textoch o filozofii vedy nazýva epistemologickou prekážkou? Aby sme na takto položenú otázku mohli odpovedat', musíme najskôr preskúmat' význam používania pojmu strážcu prahu u Bachelarda alebo v textoch, ktoré jeho myslenie inšpirovali či boli ním inšpirované. Potom bude namieste objasnit' Bachelardov pojem racionalizmu, na ktorom sa pojem epistemologickej prekážky zakladá, a následne sa bude treba dotknút aj samej prekážky a jej významu pre Bachelardovo chápanie dynamiky vedy. Až po tomto preskúmaní bude možné odpovedat' na otázku, ktorú sme položili.

No uvažovanie o prahu a prekážke nás ešte stavia aj pred tému hraníc či hraničných zón, ktoré fascinujú i desia. Bernhard Waldenfels v súvislosti s tým hovorí aj o étose uznania a zároveň narúšania hranice, hoci pripomína, že prekročením prahu sa hranica nikdy neruší, ale sa posúva. Hranica neostáva prekonaná a za nami; Waldenfels cituje Jacquesa Derridu, ked’ podotýka, že hranica „ustavične koná svoje dielo“ (Waldenfels 1998, 48). Personálna, respektíve interpersonálna geografia, ktorú možno vytušit' z Waldenfelsových textov, by sa u Bachelarda obohatila aj o epistemologickú geografiu: podobne ako jestvujú l'udia prahu a l’udia najtemnejších kútov našich obydlí, tak existujú v dejinách vedy tí, ktorí radšej prebývali v blízkosti prahu, a tí, ktorí ostávali v kútoch, desiac sa všetkého nového, čo by mohlo narušit' ich nadobudnuté poznanie. V podobnej dialektike - ako uvidíme - sa odvíja aj Bachelardovo uvažovanie o epistemológii.

\section{K obrazom dverí a prahov}

V knihe La Terre et les rêveries du repos (Zem a snenia o odpočinku) v kapitole Grotte (Jaskyňa) komentuje Bachelard slová francúzskeho orientalistu Paula Massona-Oursela, že jaskyňa je „,príbytkom bez dveri““, takto: „Dialektika úkrytu a ohrozenia si vyžaduje otvorenost'. Chceme byt' chránení, no nie uzavretí. Ludské bytie pozná zároveň hodnoty vonkajška aj vnútra. Dvere sú tak archetyp, ako aj pojem: totalizujú vedomé aj nevedomé istoty. Dvere zhmotňujú strážcu prahu (le gardien du seuil), no všetky tieto hlboké symboly sú nateraz pochované v nevedomí, ktoré sa nedotýka snov spisovatel’a. Jasné hodnoty úkrytu sú príliš živé na to, aby sme mohli odkryt' hodnoty temné" (Bachelard 1992, 186). 
Dvere zhmotňujú „strážcu prahu“ - čo tieto slová znamenajú? Dávne kultúry pripisovali moc strážcu prahu napríklad drakom, hadom alebo levom ako strážcom pokladov či cenností, prípadne božským a polobožským bytostiam, ktoré v rôznych kultúrnych imagináciách strážili vchody do l'udských obydlí, chrámov alebo celých území. Moc uzamykat' a držat' v bezpečí, nepustit' dnu ani von bola týmito mýtickými či rozprávkovými bytost’ami personifikovaná alebo „,animalifikovaná“ (pokial' išlo o strážcov-zvieratá). U Bachelarda je táto moc materializovaná, a to vo dverách ako symbole tejto moci. Ked’že dvere symbolizujú hodnoty uzavretosti, on sám ich nepotrebuje na dialektickú hru na pomedzí pocitov bezpečia na jednej strane a ohrozenia na druhej. Otvorenost' je preňho kl'účovou hodnotou, ktorá určuje aj jeho racionalizmus. Uzavretost' je, naopak, prejavom neurotickej mysle, ktorá ak chce získat' svoju slobodu, musí o ňu ešte zviest' boj - s drakmi, dverami či inými prekážkami.

V metóde takzvaného bdelého snenia, ktorú v psychoterapii využíval Bachelardov inšpirátor Robert Desoille (od neho si totiž filozof sám vypožičal pojem bdelého snenia) alebo neskôr holandský psychiater Jan Hendrik van den Berg, sa strážca prahu chápe ako prekážka alebo brzda, na ktorú takmer vždy pacient pri rozprávaní svojho príbehu narazí a snaží sa ju s pomocou terapeuta bud' prekonat', alebo sa na nej rozprávanie končí - pre Berga je ciel’om vít'azstva nad strážcom prahu akási psychická rekonkvista domova, vytvorenie svojho vlastného priestoru na bývanie vo svete (Berg 2009, 167).

Aký obraz nám teda na príkladoch jaskyne na jednej strane a dverí s ich strážcami na druhej strane Bachelard vykresl'uje? Je to obraz antropologický, je to typológia dvoch odlišných spôsobov l’udského bytia: uzavretosti a otvorenosti. Toto nazýva Bachelard „kultúrnym komplexom“, ktorý definuje ako „nereflektované postoje, ktoré ovládajú sám spôsob reflexie“. Tieto nereflektované postoje - tvrdí francúzsky filozof - môžu mat' svoju adekvátnu aj neadekvátnu formu: v prvom prípade tak kultúrny komplex „napĺňa tradíciu životom a omladzuje ju“, v druhom prípade je len „školáckym návykom“ bez imaginatívnej sily (Bachelard 1997, 26). ${ }^{1}$

Uzamknuté dvere sú však zaujímavé aj z inej perspektívy: pacienti počas van den Bergovej terapie dostávali často za tému svojich rozprávaní „kl'účc, pričom van den Berg odmieta freudovské výklady klúča ako sexualizovaného symbolu falusu. Sám Bachelard totiž hl'adal u Desoilla takú psychoanalytickú metódu, ktorá by bola

\footnotetext{
${ }^{1}$ Problematike ambivalentnej - pozitívnej i negatívnej - povahy kultúrnych komplexov sa zaoberá aj Eileen Rizo-Patron v jej skúmaní Bachelardovej hermeneutiky, psychoanalýzy a fenomenológie. Rizo-Patron takisto tvrdí, že „afektívne komplexy“ na úrovni imaginatívneho života sú analogické s ,epistemologickými prekážkami“ v Bachelardovom Formovaní vedeckého ducha (Rizo-Patron 2017, 118).
} 
alternatívou k freudizmu a nesnažila by sa u pacienta iba odblokovat' to, čo ho „brzdí“ (Hemmung), ale pomáhala by mu aj nanovo sa rozbehnút'. Toto našiel u Desoilla v pojme maxima sublimácie a skôr psychosyntézy než psychoanalýzy (Parinaud 1996, 271). Použitie kl'úča u Berga malo ukázat', čo s ním vo svojich príbehoch pacient urobí. A kl'úče u neurotikov väčšinou slúžia bud' na uzamykanie pred nebezpečenstvom, alebo ako symbol strachu odomknút' nimi dvere, za ktorými sa skrýva niečo, čo by nemalo byt' hocikým videné. Mat' kl'úč znamená mat' zodpovednost' narábat' s ním, a preto sa stáva, že neurotik sa radšej snaží kl'úč zahodit' alebo odovzdat' niekomu inému, a tým naňho preniest' svoju zodpovednost'. Neurotik dvere nerád odomyká.

Dvere sú napriek tomu, čo sme doteraz naznačili, pre Bachelarda - prinajmenšom v Poetike priestoru - vel'kou témou: ,je to celý kozmos Pootvorenia“ (Bachelard 2009, 220). Citujúc verš od Jeana Pellerina o tom, že „dvere ma vetria, vyčkávajú“, neváha povedat', že „do dverí sa vtel’uje bôžik prahu“(Bachelard 2009, 221). Takým bohom-strážcom prahov bol napríklad v rímskych časoch Limentinus ${ }^{2}$ (slovo limen označovalo v latinčine prah alebo hranicu a slúžilo ako symbol prechodu a iniciácie). V tomto zmysle sú dvere transgresívnym priestorom, v ktorom dochádza k stretnutiu a vzájomnej výmene (azda až k prepletaniu) domáceho a cudzieho. No ako upozornil Anthony J. Steinbock pri rozvíjaní témy transgresie ako hraničnej skúsenosti na princípoch Husserlovej fenomenológie, transgresia nie je iba obyčajné opustenie domova a splynutie s cudzím, ale je také „prekročenie zvnútra“, pri ktorom sa domov neopúšt’a (Steinbock 2013, 300).

Bachelard si ambivalenciu dverí (fakt, že tak otvárajú, ako aj zatvárajú) dobre uvedomuje. Preto je vo dverách - na prahu - situovaná celá dialektika otvoreného a uzavretého, interiority a exteriority. Netreba sa preto čudovat', že na dvere sa v minulosti pripevňoval obraz janusovskej tváre ako symbol dvoch pohl'adov - do minulosti i budúcnosti, dovnútra aj vonku.

Dominique Raynaud pri etnografickom skúmaní obrazu dverí v architektúre tvrdil, že podstatnou črtou symbolu dverí je jeho „nekonečná transcendencia“, čiže fakt, že dvere „predstavujú ,epifanickú dimenziu: odkazujú vždy na to, čo je nevnímatel'né“ (Raynaud 1992, 349).

Analyzovat' všetky symbolické hodnoty dverí však nie je ciel'om tohto príspevku, stačí nám poukaz na ich ambivalenciu. Mytologický obraz strážcu prahu zhmotneného v dverách samých je pre nás nosnou figúrou, ktorú sa však chceme teraz pokúsit' aplikovat' na celkom inú oblast': na epistemológiu.

${ }^{2} \mathrm{~S}$ predstavami o tomto bôžikovi sa možno stretnút' aj v Augustínovom Božom štáte (v kapitolách IV, 8 a VI, 7). 


\section{Veda na hraniciach}

Bachelard začína svoje Formovanie vedeckého ducha (kniha nesie podtitul Príspevok k psychoanalýze objektívneho poznania) úvodom, ktorý sa týka takzvanej epistemologickej prekážky, „ktorú si treba klást' ako problém vedeckého poznania“(Bachelard 1977, 13). Filozof má pod ňou na mysli taký „poznatok či pravdu“, ktoré blokujú vede prístup k jej d’alšiemu rozvíjaniu. Odvažujeme sa teda nastolit' kl'účovú otázku: Nestáva sa epistemologická prekážka pre konkrétnu vedu strážcom pra$h u$, na ktorého veda naráža a ktorého sa musí zbavit', ak chce postupovat' vpred?

Na rozdiel od dverí, ktorých lokácia v príbytku býva jasná, v prípade epistemologickej prekážky ide o neznámu. Nie vždy vieme presne určit', čo takou prekážkou je. Najčastejšie spomínaným príkladom $\mathrm{v}$ dejinách vedy by bola bezpochyby flogistónová teória: trvalo takmer sto rokov, kým chemici (postupne cez Priestleyho až po Lavoisiera) prišli na to, že sám pojem flogistónu bol prekážkou, ktorá im nedovol'ovala pohnút' sa d'alej. A dokonca aj samému Lavoisierovi ostala stát' neskôr $\mathrm{v}$ ceste d'alšia prekážka, ktorú pritom on sám pokladal za vedecký progres: pojem kalorika. Vieme tiež dobre, ako neochotne Immanuel Kant prijímal Lavoisierov dôkaz proti existencii flogistónu, takže ešte aj v predslove k druhému vydaniu Kritiky čistého rozumu, napísanom v roku 1787, čiže desat' rokov po Lavoisierovom vyvrátení flogistónovej teórie, čítame o jednom z príkladov vedeckej revolúcie, ktorú spôsobil otec tejto teórie Georg Ernest Stahl (Kant 1979, 41 - 42). Flogistón teda ako strážca prahu, ako „Limentinus vedy“, zamedzoval chémii sedemnásteho až osemnásteho storočia rozšírit’ svoje horizonty. Podobných príkladov by sme v dejinách vedy našli vel'a.

Mohlo by sa zdat', že epistemologickou prekážkou je teda všetko to, čo ešte veda nevyriešila. Nie je to tak. Skôr je ňou všetko, čo jej st'ažuje prístup k tomu, aby to odhal'ovat' a riešit' mohla. Tu sa dostávame $\mathrm{k}$ Bachelardovým pokusom o psychoanalýzu vedeckého ducha (viac sa ich dotkneme ešte $\mathrm{v}$ štvrtej časti tohto príspevku). $\mathrm{V}$ prípade prekážok poznania totiž často ide o neuvedomované predstavy (aj tu hrajú svoju rolu kultúrne komplexy v zmysle nereflektovaných postojov), a preto Bachelard uvažuje o možnostiach, ako si $\mathrm{k}$ nim môže veda zabezpečit' prístup. Byt' vnímavý k epistemologickým prekážkam ešte síce neznamená, že ich vedec odhalí, no aspoň zvyšuje možnost' takejto detekcie. Cestou k tomu má byt' podl'a neho racionalizmus.

\section{Fenomenológia študujúceho človeka}

V októbri 1949 Bachelard predniesol na Medzinárodnom kongrese o filozofii vied v Paríži prednášku na tému Filozofický problém vedeckých metód. Okrem iného v nej spomenul, že filozofia vedy, opísaná moderným spôsobom, je „fenomenológiou 
študujúceho človeka, človeka zabratého do svojich štúdií, a nielen vágna bilancia všeobecných ideí a dosiahnutých výsledkov“" (Bachelard 1972, 37). Na konci prednášky hovoril o objavovaní „fenomenológie racionalistickej húževnatosti, fenomenológie presnej skúsenosti, fenomenológie odvahy inteligencie“ (Bachelard 1972, 41). Čo presne mal pod týmito výrazmi na mysli, to ešte bude treba objasnit'.

Táto prednáška vyšla v súbore textov, ktorý po Bachelardovej smrti zostavil Georges Canguilhem s názvom Racionalistický záväzok. Hned' po nej zaradil do súboru inú Bachelardovu prednášku, ktorú filozof predniesol len pár mesiacov po spomínanom kongrese 25. marca 1950 na zasadnutí Société française de Philosophie (Francúzsku spoločnost' pre filozofiu založil na začiatku dvadsiateho storočia filozof Xavier Léon) a v ktorej sa venoval povahe racionalizmu. Zaslúži si pozornost' nielen preto, lebo rozvíja Bachelardove úvahy o racionalizme, ako ich opísal najmä v Aplikovanom racionalizme, ale na základe toho môžeme aj lepšie porozumiet' figúre racionalistu - a tým dat' odpoved' na otázku, o akej fenomenológii bola reč v Bachelardovom príhovore na Medzinárodnom kongrese v roku 1949. A to nám v konečnom dôsledku pomôže lepšie porozumiet' aj jeho pojmu epistemologickej prekážky a spôsobu, ako s ním pracoval.

Bachelardova filozofia vedy naozaj nie je len výpočtom toho, čo všetko veda $\mathrm{v}$ dejinách dosiahla, ale je sui generis fenomenológiou vedca, respektíve svojráznou antropológiou študujúceho človeka. A aj tu platí, že ,antropológia je filozofickým, nie empirickým projektom“, ktorý nevychádza ani tak z l'udskej prirodzenosti, ale skôr zo svojich dejinných prejavov (Vydrová 2016, 569).

V úvode prednášky na zasadnutí Francúzskej spoločnosti pre filozofiu Bachelard hovoril o svojej nostalgii po antropologickom skúmaní „človeka dvadsiatich štyroch hodín“ (Bachelard 1972, 47), čiže človeka, ktorý žije vo svojich skúsenostiach dňa aj noci, myslenia aj snenia. Tento antropologický holizmus bol pre Bachelarda typický. „Nočné skúsenosti““ ukazujú človeka pokojného, „ukolísaného“ vo svojich sneniach (mimochodom, on sám odporúčal l'ud'om, ktorí prežívajú nepokoj, bdelo snívat’ o vode). „Nočné skúsenosti“ sú tou čast’ou z nás, ktorá sa oddáva metafyzickým úvahám (nie prísne vedeckým), jasným ideám (ešte uvidíme, prečo sú pre Bachelarda a jeho porozumenie vede problematické) alebo poézii - ak to nerobí, ak tie okamihy iba „prespi“, nezíska svoju úplnú hodnotu a odignoruje dôležitú čast' ludskej skúsenosti.

Druhá čast' človeka sa zameriava na myslenie - presnejšie, na vedecké myslenie. To je skúsenost' človeka-racionalistu, človeka v práci, ktorý neoddychuje, ale namáha sa pri rozširovaní poznania - svojho vlastného i celého l'udstva. Skúsenost' dňa je kratšia ako skúsenost' noci, v stave spánku a oddychu zotrvávame dlhšie než v našom pohrúžení do práce. Človek-racionalista je teda len výsekom z celku; nie 
je to nevyhnutne vedec ani génius (Bachelard 1972, 52), no má sa učit' tomuto správaniu od vedcov, má ich pozorovat’ a napodobňovat' ich štýl práce. Človek-racionalista, človek niekol'kých hodín dňa určených úsiliu (čiže štúdiu, ak chceme ostat' verní etymológii latinského slova studium), musí mat' v sebe niečo, čo francúzsky filozof nazval „racionalistický tonus“ (le tonus rationaliste). Kto ho nemá, ten podl'a neho nemôže byt' v plnom zmysle racionalistom.

Človek-racionalista nežije iba zo spomienok na to, čo $u z ̌$ dosiahol, ale zo situácie, v ktorej si uvedomuje, kol'ko toho ešte nevie. Podobnú dialektiku „už a ešte“ vel’mi dobre opísal Georges Canguilhem, ked’ sa pokúsil o rozlíšenie medzi mladost'ou a starobou: mladosti patrí všetko „ešte“ (čo ešte treba dosiahnut'), zatial' čo starobe „už“ (čo sa $u \check{z}$ dosiahlo) (Canguilhem 2011, 320). Tému mladosti a staroby vedy nachádzame aj vo Formovani vedeckého ducha (Bachelard 1977, 14 a 196). Pre presnost' iba poznamenajme, že Canguilhem o tejto téme píše prvýkrát v roku 1930 a Bachelardovo Formovanie vedeckého ducha vychádza v roku 1938.

Uvažovanie o „mladosti“ racionalistického „ešte“ ponúka Bachelardovi príležitost' otvorit' tému, ktorá je preňho príznačná: filozofia predpony „re-“ (znovu). Znovuzačínanie (recommencement), opätovné čítanie (relire), opätovné usporiadanie vedeckého myslenia (reorganisation). Začínat' odznova tu však neznamená obyčajný návrat na začiatok, lebo „dnešok nemožno založit’ na včerajšku... filozofia znovuzačínania je filozofiou, ktorá nemôže opakovane začínat’ to, čo robila včera“ (Bachelard 1972, 49). Opakovat' dookola to isté (,verklíkovat"“) nie je zmyslom bachelardovského iterovania (iba ak v zmysle snenia, ktoré žije vždy zo svojich nemenných pôvodných obrazov a navracia s k nim); racionalistické opakovanie je vo svojej podstate ustavičnou reorganizáciou myslenia, neochotou uspokojit'sa s tým, čo sa dosiahlo v minulosti, ale žit' „v situácii“, neprestajne obnovovat' alebo aktualizovat' svoje poznanie. Nič, čo sa raz potvrdilo ako jasné, nie je v bezpečí pred novým preskúmaním. Lipnút' na jasnosti dosiahnutých ideí by mohlo byt' práve epistemologickou prekážkou, ktorá bráni napredovaniu. Skrátka, jasná idea môže aj oslepovat'.

Mat' všetko vyriešené by bolo pre Bachelarda agóniou vedy, upadnutím do dogmatizmu: „Racionalista bez problému je ako rozum, ktorý nemôže dýchat"“ (Bachelard 1972, 51). Takýto človek podl'a neho ostal uväznený vo svojej nočnej existencii, v komfortnej zóne, kde sa netreba namáhat'. Je neúplný, nevyvážený, bez integrity. Človek-racionalista je principiálne otvorený tomu, že všetko, čo sa dosial' naučil, možno prehádzat' a bude to treba pochopit' nanovo už len preto, lebo sa zmenia pojmy, ktorými disponuje veda. Až táto otvorenost' umožňuje Bachelardovi hovorit' o kultúrnom prerode človeka na racionalistu (Bachelard 1972, 53), o formovaní vlastnej citlivosti (aj o scitlivení samého racionalizmu) na malé problémy, lebo 
vel'ké problémy vlastne ani neexistujú. Citlivost' na detail, na drobnosti, na drobné, no zásadné zmeny a úpravy - to je základná črta človeka-racionalistu.

Okrem toho Bachelard nemá pochopenie pre osamelého racionalistu, ktorý azda aj je rozumný a šikovný, no ak svoje myšlienky nepredloží pred vedeckou obcou, ak sa neodváži konfrontovat' ich na pôde školy, univerzity či akadémie, tak je človekom, ktorý sa dobrovol’ne alebo zo strachu pred argumentačným zápasom rozhodol ostat' vydedencom, samotárom, ktorý nežije v obci. Vedecká obec je potom tým, čo človeka učí byt' autentickým racionalistom. A učí ho to prostredníctvom jediného faktu: že súčasná veda sa nezakladá na všeobecnom vzdelaní, ale na špecializácii, a je to práve špecializácia, čo podl'a Bachelarda takému človeku dodáva „racionalistický tonus“ (Bachelard 1972, 55). Všeobecné vzdelanie sa väčšinou chápe ako doména širokého prehl'adu, zatial' čo špecializácia postupuje v opačnom smere. Bachelard sa snaží ukázat', že takýto výklad je chybný a že špecializácia nie je obmedzením, ale naopak otvorením ducha. Jednotlivé špecializácie sú navzájom prepojené, tvoria spolu základ interdisciplinárnej spolupráce a vytvárajú z výsledkov práce takzvaných „regionálnych racionalizmov“ jeden spoločný racionalizmus.

Človek-racionalista podl'a Bachelarda nemôže pracovat’ sám, nie je to solitér, nie je to rybár, ktorý by osamelo vylovil poklad, ale človek, ktorý patrí do spoločenstva tých, ktorých charakterizuje dlhá cesta prípravy (Bachelard 1972, 59). Úvahu o fenomenológii študujúceho človeka Bachelard ukončí tým, že ak sa chceme stat' racionalistami, musíme racionalizmus hl'adat' tam, kde sa nachádza jeho domov: vo vedeckom myslení, „a nenazdávat' sa, že vedecký duch je duchom, ktorého sa nám dostalo v kolíske, ked' je jednoducho iba úprimný, ked' je jasný, ked' pozná pravdu a nie je ani príliš hlúpy. Človek môže byt' vel'mi inteligentný, a predsa nemusí byt' racionalistom!“ (Bachelard 1972, 60)

\section{Jasné idey ako epistemologické prekážky}

To, že pre Bachelarda sú práve jasné a zretel'né idey (princípy karteziánskej racionality) príkladmi epistemologických prekážok, nie je v jeho diele vôbec prekvapivé. Nie je to nevyhnutne útok na Descarta, ale poukázanie na fakt, že raz a navždy ustanovená jasnost' nestačí na to, aby garantovala poznanie raz a navždy, sub specie ceternitatis. Jasná idea totiž môže znejasňovat' inú oblast' skúmania.

S jasnými ideami ako prekážkami vedeckého poznania sa stretávame aj v diele Aplikovaný racionalizmus $^{3}$ (Le rationalisme appliqué), kde tieto prekážky spolu s Maine de Biranom Bachelard označuje za súčast' vedy (Bachelard 2018, 309).

\footnotetext{
${ }^{3}$ Text je dostupný v českom preklade: Bachelard, G. (2018): Aplikovaný racionalismus. In: Nový vědecký duch a dalši eseje. Praha: Malvern. Uvedená publikácia je súborom štyroch Bachelardových kníh vrátane Aplikovaného racionalizmu.
} 
Jednou vecou sú „zákerné omyly“ vo vede, inou spochybnenie základných pravidiel rozumu, ked' sa ocitáme „tvárou v tvár vzdorovitému psychologizmu jasných ideí. Rozum v takej chvíli pracuje proti sebe samému“. Dialektika pravidiel a prekážok, ktorú tu Bachelard rozvíja, dobre vystihuje normativitu jeho epistemológie. Nejde mu len o to, aby používaním základných metodologických pravidiel vyháňal falošné idey a detegované vedecké omyly, ale aby podroboval skúške aj samotné pravidlá, aby ich neváhal odvrhnút' a nahradit' inými, ak si to aktuálna úroveň vedeckého poznávania vyžaduje. Pravidlo samo, metóda sama sa totiž takisto môžu stat’ prekážkou vedeckého progresu.

Epistemologické prekážky podl'a úvodu do Formovania vedeckého ducha nie sú nikdy externé (prekážkou nie je komplexnost' či nestálost' vedeckých javov), no nedá sa pripísat' ich ani slabosti našich zmyslov či l'udskej mysle - podl'a Bachelarda spočívajú v samom akte poznávania, ktorý tým spomal'ujú, až brzdia. Etymologicky sa francúzske slovo obstacle (prekážka) viaže na situáciu, ked' niekto stojí v ceste, vo dverách a blokuje toho, kto by chcel íst' von alebo d’alej. Ako sme už poukázali, prekážky u Bachelarda súvisia vždy s „vekom“ vedca (Bachelard 1977, 14). Tento vek je oproti bežnej realite obrátený naruby. „Duch, ktorý ešte len vstupuje do vedeckej kultúry, nie je nikdy mladý. Naopak, je príliš starý, lebo je vo veku svojich predsudkov. Dosahovat' vedu znamená duchovne omladnút', prijat' náhlu premenu, ktorá musí protirečit' minulosti.“ Len dodajme, že príkladom vedeckej staroby je pre Bachelarda alchymista, ktorého nazýva doslova „starcom“, lebo „téma omladnutia je dominantnou témou alchýmie“, lebo to, čo mnohí alchymisti sami hladajú, je tajomná „,voda mladosti“ (Bachelard 1977, 196). Alchýmia je tak preňho túžbou po mladosti, ktorá sa vytráca, a alchymista tu teda na rozdiel od vedca nie je vo veku mladosti, ale vo veku starca.

Základnou epistemologickou prekážkou sú, samozrejme, naše bežné mienky, založené na praktickej užitočnosti vecí. Kým sa týchto mienok podl'a Bachelarda nezbavíme, nepohneme sa k poznaniu. Namiesto mienok musí nastúpit' kladenie problémov, duch musí mat' „zmysel pre problém“.

Ďalšou bachelardovskou prekážkou je absencia otázky: prestat' sa pýtat' a ustrnút' iba pri odpovediach - to podl'a neho uväzňuje myslenie. Taká je kultúra založená na poučkách, kde vyhrávajú „šikovné hlavičky“, ako ich nazýva: tieto hlavičky sú síce naozaj šikovné, no tým aj uzavreté, a treba ich prerobit' tak, aby boli pripravené prijat' zmenu toho, čo sa v škole naučili, respektíve čo si vštepili do pamäti.

Medzi základné epistemologické prekážky d’alej pre Bachelarda patrí aj princíp, podla ktorého chce veda zjednocovat', respektíve generalizovat' a vytvárat' homogénne systémy, ked' chce totalizovat' šŕrku myslenia do jediného celku, ktorým by vysvetl'ovala všetko. Toto neskôr nazve Georges Canguilhem vedeckými ideológiami, v ktorých 
sa vedecké výsledky zneuživajú ako argumenty, napríklad na dosiahnutie politických alebo sociálnych ciel'ov (Canguilhem 2015, 35 - 49).

Spoznat' epistemologické prekážky sa dá vždy takpovediac až post factum, ked' sa pozeráme na vedeckú minulost' a na chyby, ktorých sa vedci v minulosti dopúšt’ali. Tu sa Bachelard dostáva $k$ dištinkcii medzi historikom vedy a epistemológom (normatívnym filozofom vedy): „Historik vedy musí pracovat' s ideami ako faktmi. Epistemológ musí pracovat's faktmi ako ideami a vkladat' ich do systému myslenia. Aj zle interpretovaný fakt ostáva pre historika nad’alej faktom. No pre epistemológa je to prekážka, protimyslenie“ (Bachelard 1977, 17). Ponúka sa mu tak hned’ prvý zaujímavý moment ako príklad takto pochopenej prekážky: starost' historika o objektivitu, o to, aby nebol obvinený, že sa nedržal faktov. Epistemológ v tejto starosti rozpozná akoby strážcu prahu, ktorý mu zamedzuje prístup k preskúmaniu všetkých možností interpretácie toho istého textu alebo slova: „V tom istom období existujú za tým istým slovom také odlišné pojmy! To, čo nás tu klame, je skutočnost', že jedno a to isté slovo súčasne označuje aj vysvetluje (désigne et explique). Označovanie je rovnaké, vysvetlenie sa lísii“ (Bachelard 1977, 17). Historická epistemológia sa tak stáva novým druhom historickej práce, o ktorej Bachelardov žiak a sociológ Pierre Bourdieu povedal, že „iba história nás môže oslobodit’ od histórie“, pričom mal na mysli práve rozpor medzi kritickou historickou prácou epistemológov (explicitne spomína Canguilhema a Foucaulta) a dejinami, ktoré nazýva „väzením stelesnenej minulosti“ (Bourdieu 2000, 424).

Ako príklad si Bachelard vezme telefón, slovo, ktoré používa predplatitel', inžinier, zamestnanec telekomunikačnej spoločnosti (poskytovatel' služieb), matematik a pritom pre každého sa pojem telefónu ukazuje vždy trochu inak, v posunoch. Telefón pre nich nie je ten istý. Mimochodom to, že si Bachelard vybral za príklad práve telefón, vychádza z jeho osobných skúseností, ked’že v mladosti začínal práve ako inžinier $\mathrm{v}$ telekomunikáciách a ako tvrdí Jean-Michel Wavelet $\mathrm{v}$ už citovanej biografii, táto životná okolnost' mala významný vplyv na to, ako sa neskôr rozvíjala jeho filozofia. Práca epistemológa je pochopit' význam pojmových vzt'ahov - a to je zároveň zdolaním epistemologickej prekážky, ktorú nazval „starost’ou o objektivitu“. Pojmové vzt'ahy pritom preňho nie sú čisto logickým opisom odlišností, ale sú psychologicky zat'ažené, takže pri odkrývaní epistemologických prekážok nejde u Bachelarda o nič iné ako o jeho svojráznu „psychoanalýzu rozumu“ (Bachelard 1977, 19), o odkrývanie motivácií, ktoré viedli l'udí v minulosti a ktoré vedú i dnes k používaniu nejakých slov ako pojmov. Jednou z takých prekážok je preňho prvé pozorovanie, ktoré sa ešte odohráva pod vplyvom obrazov alebo prirodzenosti, je príliš konkrétne a vzdialené vedeckej abstrakcii, núti nás opisovat', čo vidíme, a - samozrejme - divit' 
sa. „Od pozorovania k systému: postupujeme od ohromených očí k očiam zatvoreným“" (Bachelard 1977, 20).

Okrem prekážky, ktorou je prvé pozorovanie, sú d’alšími, ktoré Bachelarda zaujímajú, tieto: prekážka hladania jednoty (už sme o nej hovorili), prekážka utilitarizmu, teda užitočnosti skúmanej veci, d’alej verbálna prekážka (pri ktorej pojem analyzujeme namiesto toho, aby sme ho zahrnuli do vedeckého systému), potom je to prekážka zle postavenej metafyziky (podl’a Bachelarda najmä naivného realizmu) a takzvaná animistická prekážka, ktorú pomohla prekonat' až fyzika dvadsiateho storočia.

\section{Záver: neurotická alebo normálna veda?}

Na začiatku sme ukázali, že za normálnych okolností si človek nemusí vytvárat' obrazy strážcov, ktorí mu znemožňujú rozvíjat' jeho postoje, prekračovat' hranice či normy. Za takých okolností mu totiž nič nestojí v ceste tak, aby sa to nedalo prekonat'. Z hladiska psychiatrie zdravý človek nepotrebuje podstupovat' liečbu metódou bdelého snenia, v ktorom by narazil na strážcu prahu, ktorý jeho rozprávanie zastavuje. Za normálnych okolností si volí a slobodne vytvára svoje normy vedenia života a svojho správania vo svete.

Čo znamená, ked' sa tento motív aplikuje na vedu v jej dejinách? Tu možno siahnut' po pojmoch normálnej vedy a jej anomálií, ako ich opísal Thomas Samuel Kuhn v Štruktúre vedeckých revolúcií. Veda, ktorá stojí pred vedeckým problémom, ktorý vie pri plnom vedomí opísat', nie je veda, ktorá sa ocitá pred prekážkou, ktorú opísat' nedokáže, lebo tá vyviera z jej nevedomia. K spôsobom nášho poznávania vždy pristupujeme vybavení nejakou metafyzikou, prípadne niekol'kými metafyzikami - a takisto s určitou, nám vlastnou obrazotvornost'ou, so sériou presvedčení, ktoré ovplyvňujú to, ako napokon pristupujeme aj k vedeckým problémom.

Keby mala byt' epistemologická prekážka vedeckým strážcom prahu, tak iba $\mathrm{v}$ tom zmysle, že si vedec uvedomuje jednoduchý fakt, že podlieha určitým neuvedomovaným predstavám a obrazom, ktoré mu môžu komplikovat' jeho vedecký progres. Nie je to bežne chápaný falibilizmus, ktorý iba pripúšt’a, že sa môže vždy mýlit', ale uvedomenie faktu, že za vedecké omyly môže často aj naša slabo rozvíjaná imaginácia.

V úvode tohto textu som napísal, že strážca prahu je poetickým naratívom, ktorý by mohol opísat' Bachelardov filozofický koncept epistemologickej prekážky. Ked' vezmeme do úvahy filozofov záujem o psychoanalýzu objektívneho poznania, plní mýtus o strážcovi prahu svoju rolu správne, ked’že je obrazom toho, čo vedca limituje. No rovnako treba dodat', že u Bachelarda tu ani zd'aleka nejde o ten typ archetypálneho obrazu, aký preňho predstavujú živly a s nimi spojené imaginácie (spomedzi tých najslávnejších sú to lietanie, domov, svieca, labyrint alebo jaskyňa). 
Strážca prahu nie je preňho kl'účový mýtus. Ak pre Bachelarda hrá v nevedomí vedca nejakú rolu obraz dverí, tak vždy dverí pootvorených, odomknutých, na prahu ktorých niet nijakého strážcu. Strážca vo dverách vedca by bol strážcom vo dverách uzavretého vedca-neurotika, ktorý sa obáva nových poznatkov, rozširovania vedomostí či presnejšie reorganizácie vedeckého myslenia v dôsledku nových poznatkov. Možno tu hovorit' v plnom rozsahu vôbec o vedcovi? Alebo by šlo iba o zberatel'a poznatkov?

Ak teda $\mathrm{v}$ bachelardovskom zmysle slova racionalistický vedec hovorí o epistemologických prekážkach, tak by mal pod nimi na mysli strážcov svojich prahov poznania len v tom zmysle, že pripúšt’a fakt, že jeho poznávanie ovplyvňujú spomínané neuvedomované obrazy alebo neadekvátne kultúrne komplexy, ktorých spresnenie, úprava, odstránenie alebo výmena by mu mohli otvorit' prístup $\mathrm{k}$ takému tematizovaniu svojej oblasti poznávania, ktorá je azda preňho v danej chvíli ako vedecká takmer nepredstavitel'ná. Čím väčšmi sa usilujeme pracovat' s našimi obrazmi, komplexmi či našou imagináciou, čím väššmi sa pokúšame tvorit’ nové obrazy, tým vyššia je šanca, že nám nové obrazy uvol'nia cestu k novému pohl’adu na disciplíny, ktorým sa venujeme. $\mathrm{V}$ tom tkvie referencialita Bachelardovej poetiky obrazov a vedy.

Inými slovami, ak sú obrazy, ktoré si v sebe nesieme, „strážcami našich prahov“, tak premôct' ich znamená vziat' si na pomoc nové a nové obrazy, trieštit' zaužívané a tradičné formy imaginácie a nahrádzat' ich vždy novými, ktoré sú nositel'mi hodnoty otvorenosti.

Vrátim sa na začiatok: Ked' niekto žije $\mathrm{v}$ predstave, že na bezpečie potrebuje obraz dverí, Bachelard mu odpovedá, že dvere nie sú dôležitým symbolom pre pocit bezpečia, že bezpečie si vyžaduje úkryt, no zároveň otvorenost'. Presne to je jeho spôsob, ako „vedeckého neurotika“ privádzat' k zrelšiemu vedeckému postoju: ponúkat' nové videnie, a tým aj celkom novú antropológiu študujúceho človeka.

\section{Literatúra}

AURELIUS AUGUSTINUS (2007): $O$ Boži obci I - II. Praha: Karolinum.

BACHELARD, G. (2018): Aplikovaný racionalismus. In: Nový vědecký duch a dalši eseje. Praha: Malvern.

BACHELARD, G. (1972): L'engagement rationaliste. Paris: PUF.

BACHELARD, G. (1977): La formation de l'esprit scientifique. Paris: J. Vrin.

BACHELARD, G. (1992): La terre et les rêveries du repos. Essai sur les images de l'intimité. Paris: José Corti.

BACHELARD, G. (1997): Voda a sny. Esej o obraznosti hmoty. Praha : Mladá fronta.

BACHELARD, G. (2009): Poetika prostoru. Praha: Malvern.

BERG, J. H. van den (2009): „Bdělý sen“ Roberta Desoille. Charakter a možnosti fenomenologické psychoterapie. In: Josef Vojvodík - Josef Hrdlička (eds.): Osoba a existence. Z perspektivy fenomenologicko-antropologické psychiatrie (1930 - 1968). Brno: Host, 152 - 189.

BOURDIEU, P. (2000): Prednáška o prednáške. Filozofia, 55 (5), 424 - 438. 
CANGUILHEM, G. (2015): Ideológia a racionalita v dejinách vied o človeku. Trnava: Filozofická fakulta Trnavskej univerzity v Trnave.

CANGUILHEM, G. (2011): Euvres complètes 1: Écrits philosophiques et politiques 1926 - 1939. Paris: J. Vrin.

KANT, I. (1979): Kritika čistého rozumu. Bratislava: Pravda.

PARINAUD, A. (1996): Bachelard. Paris: Falmmarion.

RAYNAUD, D. (1992): Le symbolisme de la porte. Essai sur les rapports du schème à l'image. Arch. \& Comport. Arch. \& Behav., 8 (4), 333 - 352.

STEINBOCK, A. J. (2013): Domáce a cudzie. Generativna fenomenológia a Husserl. Pusté Úl'any: Schola Philosophica.

RIZO-PATRON, E. (2017): Bachelard's Hermeneutics: Between Psychoanalysis and Phenomenology. In: Rizo-Patron, E. - Casey, E. S. - Wirth, J. M. (eds.): Adventures in Phenomenology: Gaston Bachelard. Albany: State University of New York.

VYDROVÁ, J. (2016): Prítomnost' človeka. Antropologický prístup Helmutha Plessnera. Filozofia, $71(7), 562-571$

WALDENFELS, B. (1998): Znepokojivá zkušenost ciziho. Praha: Oikoymenh.

WAVELET, J.-M. (2019): Gaston Bachelard, l'inattendu. Les chemins d'une volonté. Paris: L'Harmattan.

Tento príspevok vznikol na Katedre filozofie FF TU v Trnave ako súčast' grantového projektu VEGA č. 1/0174/21 s názvom Revízia antropológie: pojem l'udského v 21. storočí.

Anton Vydra

Trnavská univerzita $\mathrm{v}$ Trnave

Filozofická fakulta, Katedra filozofie

Hornopotočná 23

91843 Trnava

Slovenská republika

e-mail: anton.vydra@truni.sk

ORCID ID: https://orcid.org/0000-0002-2270-598X 